\title{
ANALISIS PRODUKTIVITAS USAHATANI PADI SAWAH DENGAN MENGGUNAKAN TRAKTOR TANGAN DAN CARA KONVENSIONAL DI KABUPATEN REJANG LEBONG
}

\author{
PRODUCTIVITY ANALYSIS OF RICE FARMING USING HAND \\ TRACTOR AND CONVENTIONAL TECHNOLOGY REJANG LEBONG \\ DISTRICS
}

\author{
Eddy Silamat, Yuwana dan M. Zulkarnain Yuliarso ${ }^{3}$ \\ Program Studi Magister Agribisnis Fakultas Pertanian Universitas \\ Universitas Bengkulu
}

\begin{abstract}
The aims of this research are to (1) determine factors that affect rice farmers decision to use hand tractor or not (conventional), (2) analyze the productivity of rice using hand tractors and conventional technique. (3) Calculate the income of rice farmers that used tractors and conventional. The number of samples taken were 41 rice farmers who used hand tractors in the village of Rimbo Recap and the ones who used conventional technique 29 persons in Watas Marga village. The systems of farming was the same both in Watas Marga village and in Rimbo Recap. Sampling was conducted by interview using questionnaire to collect primer data and secunder data. The method of research was survey using the formula Slovin. The result of study concluded that the land space and perception of labor significantly affected the farmer's decision to use the hand tractors, while the perception of farmers on hand tractors did not affect significantly on the farmer's decision to use hand tractors in agricultural land preparation. Factors that affected the productivity were seeds $4.569 t$ count $>t$ table of 2.564 and labor $8.936 t$ count $>t$ table of $2.464 t$ count $>t$ table 2.042 and labor $8.936 t$ count $>$ t table of 2.464 with 99\% confidence level. Insectiside had significant effect on productivity of rice at 95\% level. The value of $t$ count was $2.479>t$ table (2.042). $T$ test had a negative value. Dummy showed decrease in productivity by $0.2077 \%$ if the farmer did not use a hand tractor. Incomes of farmers who used both tractors and conventional technique showed no significant difference. Income of farmers who used tractors was Rp. 9.014.727/MT or Rp. 11. 302.316/Ha and farmers' income whoutilize conventional technique was Rp. 9.041.365/MT or Rp. 11.349.945/Ha. The calculation results based on different incomes concluded that change in rice farming systems did not significantly effect on income benefit.
\end{abstract}

Keywords: rice paddy, hand tractors, productivity, revenue. 


\section{PENDAHULUAN}

Kabupaten Rejang Lebong dibentuk berdasarkan Undang-undang No. 4 tahun 1956 tentang pembentukan daerah otonomi kabupaten-kabupaten dalam lingkungan daerah Propinsi Sumatera Selatan. Kabupaten Rejang Lebong memiliki karakteristik perekonomian yang mengarah pada sektor pertanian, mencakup pertanian tanaman pangan, peternakan, perkebunan, kehutanan dan perikanan air tawar. Karakteristik ekonomi tersebut didukung oleh ketersediaan sumberdaya alam, sarana dan prasarana yang cukup memadai, serta kondisi sosial budaya masyarakat yang agraris. Secara teoritis hal ini akan mendorong pengembangan sektor pertanian dan perdagangan lebih cepat dalam pembangunan ekonomi wilayah dalam menciptakan pertumbuhan ekonomi menjadi lebih terarah.

Pembangunan Kabupaten Rejang Lebong sejalan dengan rencana pembangunan jangka menengah daerah (RPJMD) Propinsi Bengkulu tahun 2005-2010, melalui peningkatan dana anggaran pembangunan infrastruktur, sarana dan prasarana public. Pelaksanaan pekerjaan dilakukan pada tahun jamak untuk masa 3 (tiga) tahun angaran yakni pemberian traktor tangan bersubsidi dalam rangka peningkatan produksi pangan kepada petani di Propinsi Bengkulu. Selanjutnya diteruskan pada rencana pembangunan jangka menengah daerah (RPJMD) tahun 2010-2015 yakni menjaga ketahanan pangan, pengembangan agribisnis dan meningkatkan kesejahteraan petani.

Peningkatan produksi padi dapat dilakukan dengan intensifikasi pertanian, dan kegiatan budidaya yang penting dalam intensifikasi pertanian adalah pengolahan tanah. Sistem olah tanah yang sering digunakan petani diantaranya adalah olah tanah intensif, olah tanah minimum dan tanpa olah tanah. Segala tindakan seperti pengolahan tanah akan menggangu ekosistem tanah khususnya organisme tanah. Pengolahan tanah menjadi awal kegiatan budidaya pertanian sebelum kegiatan lainnya dilakukan, untuk itu pengolahan tanah perlu diupayakan secara efektif dan efisien karena menyangkut kualitas dan ketepatan waktu pengolahan. Pengolahan tanah yang efektif dan efisien dapat ditempuh dengan cara mekanis menggunakan traktor-traktor pertanian.

Pada umumnya traktor hanya dapat bekerja optimal pada tanah yang permukaannya datar. Pada kondisi tanah yang cocok traktor mampu mengolah tanah dengan tempo lebih singkat dan hasil kualitas pengolahan tanahnya lebih tinggi bila dibandingkan dengan cara konvensional (Nursidah, 2003). Usahatani padi sawah memerlukan teknik budidaya tersendiri sesuai dengan keadaan tanah dan lingkungannya. Kegagalan budidaya dapat menyebabkan gagal panen serta merusak tanah dan lingkungannya. Padi sawah dapat dibudidayakan pada lahan sawah tadah hujan dan lahan sawah beririgasi.

Menurut Las (2002) dalam Susanto dkk (2003), peran peningkatan produktivitas (teknologi) dalam peningkatan produksi padi mencapai 56,10\%, 
per luas areal. Guna meningkatkan produktivitas padi di Kabupaten Rejang Lebong, Gubernur Bengkulu telah memberikan bantuan traktor tangan sebanyak 300 (tiga ratus) unit pada tahun 2010 untuk kelompok tani, tersebar di seluruh desa atau kelurahan di wilayah Kecamatan Kabupaten Rejang Lebong. Jumlah tersebut cukup besar bila dibandingkan dengan jumlah dari program traktor tangan bersubsidi dari Departeman Pertanian sebelum tahun 2010 yakni sebanyak 42 (empat puluh dua) unit traktor tangan, dan dilanjutkan pada tahun 2010 sebanyak 2 (dua) unit traktor tangan.

Program ini selain bertujuan untuk meningkatkan produksi padi juga bertujuan untuk memperkenalkan teknologi pengolahan tanah terhadap petani khusus traktor tangan. Traktor tangan sebenarnya bukanlah hal yang baru bagi sebagian petani terutama bagi petani modern yang memiliki kemampuan ekonomi yang tinggi, namun bagi sebagian petani yang memiliki ekonomi rendah terutama didaerah pedesaan traktor tangan menjadi awam bagi mereka. Untuk memperkenalkan traktor tangan terutama pada petani yang berada dipedesaan, yang biasanya melakukan usahataninya secara konvensional. Untuk itu perlunya adanya informasi dan pemahaman yang baik bagi petani terhadap traktor tangan. Informasi dan pemahaman yang diberikan diharapkan dapat merubah pola pikir petani yang tadinya konvensional menjadi lebih modern. Untuk itu pembangunan persepsi yang baik terhadap traktor tangan dan ketersedian tenaga kerja terutama dibidang pertanian, yang sangat dipengaruhi oleh sektor lain selain sektor pertanian.

Berdasarkan uraian di atas rumusan tujuan dari penelitian ini adalah: (a) Menganalisis faktor-faktor yang mempengaruhi keputusan petani padi sawah untuk menggunakan traktor tangan, (b) Menganalisis produktifitas petani padi sawah yang menggunakan traktor tangan dan konvensional, dan (c) Menghitung pendapatan petani padi sawah yang menggunakan traktor tangan dan konvensional.

\section{METODE PENELITIAN}

Penelitian dilakukan di wilayah administratif Kabupaten Rejang Lebong Provinsi Bengkulu selama 4 (empat) bulan, yaitu bulan Juli - Oktober tahun 2013. Sebagai responden yang merupakan obyek penelitian adalah petani padi sawah diketahui jumlahnya dsebanyak 234 keluarga yang secara kontinyu berusahatani padi sawah.

Untuk mendapatkan sampel yang dapat menggambarkan populasi, maka penentuan sampel penelitian ini menggunakan rumus Slovin dalam Umar, 2004. Dari jumlah populasi tersebut dengan tingkat kelonggaran ketidaktelitian sebesar 10\%, maka dengan menggunakan rumus di atas diperoleh sampel sebanyak 70 petani. Penentuan sampel dilakukan secara acak sederhana tanpa memperlakukan strata dalam populasi (simple random 
sampling), dengan harapan bahwa setiap elemen populasi mempunyai kesempatan yang sama sebagai sampel.

Data yang dikumpulkan adalah data primer dan data sekunder. Data primer diperoleh melalui pengamatan langsung terhadap objek penelitian. Data sekunder diperoleh dari literature-literatur serta dinas maupun instansi terkait yang memiliki sumber-sumber dalam penelitian ini.

Penelitian dilakukan dengan menggunakan metode survai (survey method). Pengumpulan data dilakukan dengan cara wawancara kepada responden berdasarkan daftar pertanyaan (kuesioner) yang telah dipersiapkan.

\section{Analisis Faktor-Faktor Yang Mempengaruhi Petani Dalam Menggunakan Traktor Tangan}

Analisis regresi yang digunakan dalam penelitian ini adalah analisis regresi logit. Variabel terikat dalam regresi logit bersifat biner dikotomi yaitu memiliki nilai yang kontinyu 1 dan 0 .

Model logit dinyatakan dalam persamaan sebagai berikut:

(1). $P_{i}=(1+e-X i \beta)-1$

(2). $\operatorname{Ln} P_{\mathrm{i}} /\left(1-\mathrm{P}_{\mathrm{i}}\right)$

(3). $Z_{i}=\beta_{1}+\beta_{2} X_{i}$

dimana: Zi adalah Log dari odds ratio , B adalah Intercept, $\mathrm{X}$ adalah variabel bebas yang menentukan petani menggunakan traktor tangan, yang terdiri adri Luas lahan $\left(X_{1}\right)$, Persepsi petani terhadap ketersediaan tenaga kerja $\left(X_{2}\right)$, dan Persepsi petani terhadap penggunaan traktor tangan $\left(X_{3}\right)$.

\section{Produktivitas Usahatani}

Untuk mengetahui produktivitas usaha tani padi sawah di Kabupaten Rejang lebong digunakan persamaan sebagai berikut:

$$
\text { Produktifitas Usahatani }=\frac{\text { Jumlah Produksi }(\mathrm{kg})}{\text { Luas Lahan }(\mathrm{ha})}
$$

Untuk mengetahui faktor yang mempengaruhi produktifitas, dilakukan analisis menggunakan regresi linier berganda. Model yang dibuat merupakan hubungan fungsional antara faktor: luas lahan $\left(X_{1}\right)$, benih $\left(X_{2}\right)$, pupuk $\left(X_{3}\right)$, jumlah tenaga kerja $\left(\mathrm{X}_{4}\right)$, dan insektisida $\left(\mathrm{X}_{5}\right)$, terhadap produktivitas $(\mathrm{Y})$. Hubungan fungsional tersebut dalam model regresi linier berganda dapat dirumuskan sebagai berikut:

$$
\mathrm{Y}=\mathrm{a}+\alpha_{1} \mathrm{X}_{1}+\alpha_{2} \mathrm{X}_{2}+\alpha_{3} \mathrm{X}_{3}+\alpha_{4} \mathrm{X}_{4}+\alpha_{5} \mathrm{X}_{5}+\mathrm{D}+\mathrm{U}
$$




\section{Analisis Pendapatan Usahatani}

Data-data yang dapat menentukan tingkat pendapatan usaha tani padi sawah di Kabupaten Rejang Lebong yang telah terkumpul ditabulasikan kemudian dianalisa dengan formula dasar kuantitatif yang terdiri dari analisa penerimaan dan pendapatan. Menurut Bunasor (2006) keberhasilan produksi usahatani pada akhirnya dinilai dari besarnya pendapatan (Net Return) yang diperoleh darikegiatan usahatani. Besarnya pendapatan didapat dengan menggunakan rumus sebagai berikut:

$$
\begin{aligned}
& \mathrm{NR}=\mathrm{TR}-\mathrm{TC} \\
& \mathrm{TR}=\mathrm{P} \times \mathrm{Y} \\
& \mathrm{TC}=\mathrm{TFC}+\mathrm{TVC}
\end{aligned}
$$

dimana: NR adalah Net Revenue (Pendapatan), TR adalah Total Revenue (Total Penerimaan), TC adalah Total Cost (Total Biaya), P adalah Harga Tiap Satuan Produk, Y adalah Total Produk, TFC adalah Total Fixed Cost (Total Biaya Tetap), dan TVC adalah Total Variabel Cost (Total Biaya Variabel)

Untuk melihat perbedaan pendapatan antara petani yang menggunakan maupun yang tidak menggunakan traktor tangan dapat dilakukan dengan uji-t dengan tingkat kepercayaan $95 \%$ dengan persamaan sebagai berikut:

$$
\begin{aligned}
& t=\frac{X t-X t t}{\sqrt{S P^{2}\left(\frac{1}{N t}+\frac{1}{N t t}\right)}} \\
& S P^{2}=\frac{(N t-1) S t^{2}+(N t t-1) S t t^{2}}{(N t+N t t)-1} \\
& S t^{2}=\frac{\sum_{n-1}^{n}(X t-X t t)^{2}}{N t-1} \\
& S t t^{2}=\frac{\sum_{n-1}^{n}(X t t-X t)^{2}}{N t t-1}
\end{aligned}
$$

keterangan: $\mathrm{Xt}$ adalah Pendapatan petani yang menggunakan traktor tangan, $\mathrm{Xtt}$ adalah Pendapatan petani yang tidak menggunakan traktor tangan, $\mathrm{Xt}$ adalah Rata-rata pendapatan petani yang menggunakan traktor tangan, $\mathrm{Xtt}$ adalah Rata-rata pendapatan petani yang tidak menggunakan traktor tangan, $\mathrm{St}^{2}$ adalah Keragaman petani yang menggunakan traktor tangan, $\mathrm{Stt}^{2}$ adalah Keragaman petani yang tidak menggunakan traktor tangan, SP adalah Keragaman sampel, Nt adalah Jumlah sampel petani yang menggunakan 
traktor tangan, dan $\mathrm{Ntt}$ adalah Jumlah sampel petani yang tidak menggunakan traktor tangan.

\section{HASIL DAN PEMBAHASAN}

Dari hasil penelitian diketahui bahwa jumlah responden yang menggunakan traktor tangan adalah sebanyak 41 orang (pilihan 1) atau 58,57 persen dari jumlah keseluruhan responden dan yang tidak menggunakan sebanyak 29 orang responden (pilihan 0) atau 41.43 persen. Hal ini menunjukkan bahwa jumlah petani padi sawah yang menggunakan traktor tangan lebih banyak bila dibandingkan dengan jumlah petani padi sawah konvensional. Pengaruh faktor luas lahan, persepsi petani terhadap tenaga kerja dan persepsi terhadap penggunaan traktor tanggan di Kabupaten Rejang Lebong dalam penelitian ini, pengambilan hipotesis dilakukan dengan melihat nilai probabilitas ( $p$-value). Jika nilai p-value lebih kecil dari nilai alpha $\alpha$ maka dengan tingkat keyakinan (1- a) hipotesis $\mathrm{H}_{0}$ ditolak, (Gujarat 2003). Hasil perhitungan dengan menggunakan program shazamp analisis logit dapat dilihat pada Tabel 1 .

Dari hasil analisis Tabel 1 dapat diketahui bahwa secara bersama-sama luas lahan, persepsi petani terhadap ketersediaan tenaga kerja tidak berpengaruh nyata terhadap keputusan petani menggunakan traktor tangan sedangkan persepsi petani terhadap penggunaan traktor tangan, berpenggaruh nyata terhadap keputusan petani untuk menggunakan traktor tangan dalam pengolahan lahan pertanianya.

Tabel 1. Hasil Estimasi pada Faktor-faktor yang Mempengaruhi Keputusan Petani Padi Sawah Menggunakan Traktor Tangan.

\begin{tabular}{lccc}
\hline \multicolumn{1}{c}{ Variabel Bebas } & Koefisien Regresi & Standard Error & t-hitung \\
\hline Luas Lahan (X1) & -0.078888 & 0.1320 & -0.5974 \\
Persepsi TK (X2) & -0.29376 & 0.4773 & -0.6155 \\
Persepsi Traktor (X3) & 0.64989 & 0.1846 & $3.521^{*}$ \\
Konstanta & -0.44102 & 1.5540 & -0.2837 \\
t-tabel & 2.600 & & \\
(R2) & 0.1311 & & \\
\hline
\end{tabular}

Ket. $\left(^{*}\right)$ Berpengaruh Nyata Pada taraf kepercayaan 99\%

Sumber : data primer diolah 2014

Hasil estimasi nilai R2 sebesar 13.11\% menunjukkan bahwa keputusan petani untuk menggunakan, maupun tidak menggunakan traktor tangan di 202 | Eddy Silamat, Yuwana dan M. Zulkarnain Yuliarso, Analisa ... 
dalam pengolahan lahan pada usahatani padi sawah, dipengaruhi oleh variable lain yang tidak terdapat di dalam model. Contohnya kekuatan (tenaga), bila dibandingkan tenaga mesin dan tenaga manusia maupun tenaga hewan ternak dimana tenaga mesin jauh lebih besar dan cendrung stabil bila dibangingkan dengan tenaga manusia ataupun hewan ternak. Tenaga atau kekuatan manusia sangat dipengaruhi dari faktor usia, asupan gizi maupun suplemen untuk menghasilkan energi. Tenaga manusia juga memiliki kecendrungan berubahubah terutama pada waktu pagi dan sore hari, pada kondisi ini tenaga manusia lebih stabil sedangkan pada siang hari cendrung menurun, begitu pula halnya dengan tenaga ternak hanya saja bedanya keinginan manusia untuk menyelesaikan suatu pekerjaan juga dipengaruhi oleh suasana hatinya.

Untuk melihat pengaruh masing-masing variabel yang diteliti digunakan dengan membandingkan nilai t-hitung dan t-tabel. Berdasarkan hipotesis $\mathrm{H}_{1}$ ditolak dan $\mathrm{H}_{0}$ diterima apabila t-hitung < t-tabel yang berarti tidak ada pengaruh antara kedua variable, dan $\mathrm{H}_{1}$ diterima dan $\mathrm{H}_{0}$ ditolak apabila $\mathrm{t}$ hitung > t-tabel yang berarti ada pengaruh antara kedua variabel. Pengaruh masing-masing variabel terhadap keputusan petani dijelaskan secara rinci sebagai berikut:

\section{Luas Lahan}

Luas lahan memiliki nilai koefisien sebesar 0.078888, t-hitung sebesar -0.5974 lebih kecil dibanding t-tabel $0.01 \%$ dengan nilai 2.600 maka $\mathrm{H}_{0}$ diterima dan $\mathrm{H}_{1}$ ditolak. Artinya luas lahan tidak berpengaruh terhadap keputusan petani untuk menggunakan traktor tangan. Atau dengan kata lain luasan lahan yang dimiliki petani tidak dapat mempengaruhi keinginan petani untuk menggunakan traktor tangan. Hal ini sejalan dengan hasil penelitian Hamidah dan Soedarto (2006), yang melakukan penelitian tentang Analisis Oprasional Traktor Tangan. Hasil analisis yang dilakukan menemukan faktor ketersediaan jaringan dan pola tanam padi berdampak pada peningkatan pengolahan lahan menggunakan traktor tangan. Dengan demikian penggunaan traktor tangan lebih kepada ketersediaan jaringan yang mudah diakses dan pola tanam yang dikembangkan petani pada usahataninya.

\section{Persepsi Terhadap Tenaga Kerja}

Persepsi terhadap tenaga kerja memiliki koefisien sebesar -0,29376 nilai t-hitung -0.6155 lebih kecil dibanding t-tabel $0.01 \%$ sebesar 2.600 , maka $\mathrm{H}_{0}$ diterima dan $\mathrm{H}_{1}$ ditolak. Artinya persepsi petani padi sawah terhadap ketersedian tenaga kerja tidak berpengaruh terhadap keputusan petani untuk menggunakan traktor tangan. Atau dengan kata lain jumlah tenaga kerja yang tersedia untuk berusahatani terutama didalam pengolahan tidak 
berpengaruh terhadap keputusan petani terhadap keinginanya untuk menggunakan traktor tangan.

Ketersediaan tenaga kerja terhadap pengolahan lahan pada usahatani padi dipengaruhi beberapa faktor, diantaranya adanya musim panen komoditi perkebunan yang bersamaan dengan musim tanam padi. Ketersediaan tenaga kerja dibidang pertanian juga dipengaruhi oleh tingkat pendidikan, usia, jenis kelamin dan kesempatan memiliki pekerjaan disektor lain selain sektor pertanian. Pada sektor pertanian yang berskala rumahan terutama pada kegiatan pengolahan lahan, pada kegiatan ini termasuk kegiatan lainya seperti menyemai, penanaman, perawatan sampai pemanenannya dimana kekuatan fisik maupun otot lebih diutamakan, hal ini mengakibatkan manusia lebih cendrung memilih sektor pertanian sebagai pilihan terakhir dalam memenuhi kebutuhan hidupnya.

\section{Persepsi terhadap penggunaan traktor tanggan}

Persepsi terhadap penggunaan traktor tangan memiliki koefisien sebesar 0.64989, nilai t-hitung sebesar 3.521 lebih besar dari t-tabel $0.01 \%$ yang nilainya 2.600 maka $\mathrm{H}_{0}$ ditolak dan $\mathrm{H}_{1}$ diterima. Artinya persepsi petani terhadap penggunaan traktor tanggan sangat mempengaruhi keputusan petani untuk menggunakan traktor tangan, dengan kata lain persepsi petani terhadap penggunaan traktor tangan merupakan faktor yang menentukan keputusan petani untuk menggunakan traktor tangan. Sejalan dengan penelitian (Kamila, 2011) tentang Tingkat Adopsi Teknologi Terhadap Pelaksanaan PTT Padi Sawah di Kecamatan Tugumulyo Kabupaten Musi Rawas. Hasil penelitian menyatakan intensitas dan banyaknya pelatihan yang diikuti oleh petani serta ketersediaan sarana dan prasarana produksi berpengaruh nyata terhadap adopsi komponen teknologi pengelolaan tanaman terpadu. Hal ini diperkuat dengan penelitian Hamidah dan Soedarto (2006) yang menyatakan kwalitas layanan, dimana dampak dari penggunaan traktor tangan adalah waktu pengolahan tanah menjadi dapat dipercepat, sehinga tanam serempak dapat dilaksanakan.

Persepsi petani terhadap penggunaan traktor tangan biasanya menjadi barometer bagi petani, jika dihubungan dengan masalah keputusan untuk menggunakan traktor tangan. Persepsi yang baik terhadap sarana produksi pertanian terutama traktor tangan, akan berdampak pada keputusan petani untuk menggunaan traktor tangan sebagai penunjang utuk melakukan usahataninya.

\section{Produksi dan Produktivitas Usahatani Padi Sawah}

Tinggi rendahnya produksi pertanian biasanya ditentukan oleh tingkat penerapan teknologi pertanian yang digunakan petani. Salah satu indikatorya 
adalah penggunaan sarana produksi seperti penggunaan pupuk, pestisida, benih, dan tenaga kerja. Produksi pertanian di sini terdiri dari jumlah gabah yang dihasilkan oleh petani dalam satu kali musim tanam, yang diperoleh dalam bentuk gabah kering panen (GKP) dengan satuan kilogram. Untuk melihat lebih jelas rata-rata produksi dan produktivitas usahatani padi sawah yang menggunakan traktor tangan dan cara konvensional di daerah penelitian, dapat dilihat pada Tabel 2.

Tabel 2. Rata-rata Produksi dan Produktivitas Usahatani Padi Sawah Dengan Menggunakan Traktor Tangan dan Cara Konvensional

\begin{tabular}{lcc}
\hline \multirow{2}{*}{\multicolumn{1}{c}{ Uraian }} & Traktor & Konvensional \\
\cline { 2 - 3 } & Jumlah & Jumlah \\
\hline Rata-rata Produksi (Kg) & 5353.39 & 5331.55 \\
Rata-rata Luas Lahan $(\mathrm{Ha})$ & 0.7976 & 0.7966 \\
Rata-rata Produktivitas $(\mathrm{Kg} / \mathrm{Ha})$ & 6712.20 & 6693.29 \\
\hline
\end{tabular}

Sumber : data primer diolah 2014

Tabel 2 menunjukkan rata-rata produksi petani padi sawah yang menggunakan traktor tangan yaitu $5.353 .39 \mathrm{Kg} / \mathrm{MT}$, diatas rata-rata petani padi sawah yang tidak menggunakan traktor tanggan yaitu $5.331,55 \mathrm{Kg} / \mathrm{MT}$, dengan luasan lahan relatif sama antara petani yang menggunakan traktor tanggan dan cara konvensional. Produktivitas diperoleh dari penjumlahan antara rata-rata produksi dibagi dengan rata-rata luas lahan. Tabel 2 menunjukan produktivitas usahatani padi sawah di daerah penelitian adalah $6.712 .20 \mathrm{Kg} / \mathrm{Ha}$ untuk petani yang menggunakan traktor tangan, dan 6.693.29 $\mathrm{Kg} / \mathrm{Ha}$ untuk cara konvensional. Jadi dapat disimpulkan bahwa produktivitas usahatani padi sawah baik yang menggunakan traktor tangan dan cara konvensional tidak menunjukkan angka yang begitu signifikan.

\section{Analisis Faktor-Faktor Yang Mempengaruhi Produktivitas}

Pendugaan fungsi produksi regresi linear berganda dengan metode Ordinary Last Square (OLS), memberikan gambaran kinerja rata-rata dan proses produksi petani pada tingkat teknologi yang ada. Hasil pendugaan menunjukkan bahwa, fungsi produksi rata-rata yang terbentuk cukup baik (best fit) menggambarkan perilaku petani di dalam proses produksi. Koefisien determinasi dan fungsi produksi rata-rata diperoleh bernilai positif, dengan nilai t-hitung rata-rata lebih besar dan t-tabel pada $\alpha=5 \%$. Input-input yang digunakan dalam model fungsi produksi rata-rata dapat menjelaskan $100 \%$ dan variasi padi sawah di daerah penelitian pada Tabel 3. disajikan paramater dugaan fungsi produksi dan nilai signifikansinya. 
ISSN: $1412-8837$

Tabel 3. Parameter Dugaan Analisis Regresi Berganda

\begin{tabular}{lccr}
\hline \multicolumn{1}{c}{ Variabel Input } & Koefisien Regresi & Standar Error & t-hitung \\
\hline (Constant) & -1589.3 & 230.7 & -6.8890 \\
Luas lahan (X1) & 34.89000 & 102.8 & 0.3393 \\
Benih (X2) & 0.02567 & 0.005618 & $4.569^{*}$ \\
Tenaga Kerja (X3) & 0.00192 & 0.0002148 & $8.936^{*}$ \\
Pupuk (X4) & 0.00046 & 0.0005070 & -0.9021 \\
Insectisida (X5) & 0.00139 & 0.0005636 & $2.479^{* *}$ \\
Dummy (X6) & -16.0650 & 77.33 & -0.2077 \\
nilai P & 0.000 & & \\
R2 & 0.9643 & & \\
t-tabel 0.05 & 2.0420 & & \\
\multicolumn{1}{c}{ t-tabel 0.01 } & 2.5640 & & \\
Ket. ( ) Berpeng & & &
\end{tabular}

Ket. $\left(^{*}\right)$ Berpengaruh nyata pada taraf kepercayaan $99 \%$

$(* *)$ Berpengaruh nyata pada taraf kepercayaan $95 \%$

Sumber : data primer diolah 2014

Pengaruh masing-masing variabel penelitian terhadap produktivitas padi sawah di daerah penelitian dijelaskan secara rinci sebagai berikut:

\section{Luas Lahan}

Luas lahan memiliki nilai koefisien sebesar 34.890 nilai t-hitung 0,3393 lebih kecil dari t-tabel 0,05\% sebesar 2,042 maka $\mathrm{H}_{1}$ ditolak dan $\mathrm{H}_{0}$ diterima. Artinya luas lahan tidak berpengaruh nyata terhadap peningkatan produktivitas usahatani padi sawah yang dikembangkan petani baik menggunakan traktor tangan maupun dengan cara konvensional. Hal ini dapat terjadi jika penambahan luas lahan yang dilakukan untuk usahatani padi yang dilakukan tidak disertakan penambahan faktor input lainya. Penambahan luasan lahan yang bertujuan untuk meningkatkan produktivitas harus disertakankan dengan penambahan input dari faktor lain.

\section{Benih}

Benih memiliki koefisien regresi sebesar 0.025669 , nilai t-hitung sebesar 4.569 lebih besar dari t-tabel 0,01\% sebesar 2,564 maka $\mathrm{H}_{1}$ diterima atau $\mathrm{H}_{0}$ ditolak. Artinya jumlah benih yang digunakan berpengaruh nyata terhadap produktivitas usahatani padi sawah baik yang menggunakan traktor tangan maupun dengan cara konvensional. Jadi jika jumlah benih padi ditambah 
sebesar satu-satuan, maka produktivitas padi sawah di daerah penelitian akan meningkat sebesar 4.569 satu-satuan tanpa harus menambah input dari faktor lainya.

\section{Tenaga Kerja}

Tenaga kerja memiliki nilai koefisien sebesar 0,0019192, nilai t-hitung sebesar 8.936 lebih besar dari t-tabel 0,01\% sebesar 2,564 maka $\mathrm{H}_{1}$ diterima atau $\mathrm{H}_{0}$ ditolak. Artinya tenaga kerja sangat berpengaruh nyata terhadap produktivitas usahatani padi sawah baik yang menggunakan traktor tangan maupun dengan cara konvensional. Penambahan tenaga kerja yang dilakukan didalam usahatani padi sawah akan berdampak pada ketelitian serta optimalnya pada setiap kegiatan produksi, pada tingkat produksi optimal akan menghasilkan produktivitas yang optimal pula.

\section{Pupuk}

Pupuk memiliki nilai koefisien sebesar 0.00045773 , nilai t-hitung sebesar $-0,9021$ lebih kecil dari t-tabel $0.05 \%$ sebesar 2,042 maka $\mathrm{H}_{1}$ ditolak atau $\mathrm{H}_{0}$ diterima. Artinya pupuk tidak berpengaruh nyata terhadap produktivitas usahatani padi sawah baik yang mengunakan traktor tangan maupun cara konvensional. Dengan kata lain jika dilakukan penambahan pupuk di dalam usatani padi sawah, hal tersebut tidak akan meningkatkan jumlah produktivitas padi sawah didaerah penelitian. Pupuk merupakan sumber makanan untuk pertumbuhan bagi tanaman, akan tetapi pupuk hanya dapat diberikan sesuai dosis yang dibutuhkan oleh tanaman yang disesuaikan dengan anjuran terutama pada pupuk-pupuk kimia. Pemberian pupuk kimia secara berlebihan akan mengakibatkan kejenuhan pada tanaman, pada jenis pupuk kimia tertentu jika diberikan secara berlebihan berakibat pada penurunan hasil bahkan dapat mengakibatkan matinya tanaman. Hal ini tidak berlaku terhadap pupuk organik, pupuk organik memiliki sifat ramah lingkungan dan sangat dianjurkan untuk semua tanaman.

\section{Insektisida}

Insektisida mempunyai nilai koefisien sebesar 0.0013972, dimana nilai thitung sebesar 2.479 lebih besar dari t-tabel 0,05\% sebesar 2,042 maka $\mathrm{H}_{1}$ diterima atau $\mathrm{H}_{0}$ tolak. Artinya penggunaan insektisida oleh petani berpengaruh terhadap produktivitas usahatani padi sawah yang menggunakan traktor tangan dan cara konvensional. Insektisida berfungsi sebagai imunisasi bagi tanaman, pemberian Insektisida bagi tanaman sebagai langkah perlindungan tanaman dari serangan hama dan penyakit yang akan menyerang tanaman maupun yang telah menyerang tanaman yang diusahakan. Tujuanya adalah untuk mempertahankan produktivitas 
padi sawah yang diusahakan oleh petani, agar tidak berakibat pada penurunan hasil atau pada tingkat terparah adalah gagal panen yang berakibat pada kerugian petani.

\section{Dummy}

Dummy memiliki nilai koefisien regresi sebesar -16.065 , nilai t-hitung sebesar -0,2077 lebih kecil dari t-tabel 0,05\% sebesar 2,042. Dengan demikian $\mathrm{H}_{1}$ tolak atau $\mathrm{H}_{0}$ diterima. Artinya kedua cara ini yaitu penggunaan traktor tangan dan cara konvensional yang dilakukan petani, dalam pengolahan lahan pertanianya tidak berpengaruh nyata terhadap peningkatan produktivitas usahatani padi sawah yang dilakukan petani. pada kedua cara penggolahan lahan yaitu dengan menggunakan traktor tangan dan cara konvensional diperoleh nilai negatif, hal ini menunjukan adanya kecendrungan masing-masing cara penggolahan lahan yang menggunakan traktor tangan dan cara konvensional. Kecendrungan tersebut dapat dilihat dari segi keuntungan teknis, keuntungan ekonomis, dan keuntungan waktu untuk melihat cara yang dianggap paling mengguntungkan bagi petani.

\section{a. Keuntungan teknis}

Pekerjaan pengolahan tanah memerlukan tenaga yang sangat besar, sehingga dibutuhkan banyak tenaga kerja. Dengan tenaga yang besar, yang dimiliki peralatan mekanis, pekerjaan yang berat akan dengan mudah dikerjakan, hasil pengolahan tanah secara mekanis dapat lebih dalam.

\section{b. Keuntungan ekonomis}

Berdasarkan hasil penelitian (di Pulau Jawa), biaya pengolahan tanah per hektar dengan teraktor akan lebih murah dibanding menggunakan tenaga manusia maupun hewan. Penurunan biaya pengolahan tanah ini tentunya akan meningkatkan keuntungan para petani

\section{c. Keuntungan waktu}

Dengan tenaga yang cukup besar, tentunya pengolahan tanah yang dilakukan secara mekanis akan lebih cepat. Untuk beberapa tanaman yang berumur pendek, sisa waktu yang tersedia ini dapat dipakai untuk melakukan budidaya lagi. 


\section{Perhitungan Biaya Usahatani Padi Sawah}

\section{Biaya Tidak Tetap}

Dalam berusaha tani diperlukan berbagai macam input dan untuk mendapatkan input tersebut diperlukan biaya, yang dikenal dengan biaya produksi. Biaya produksi meliputi nilai dari semua faktor yang digunakan baik dalam bentuk barang maupun jasa selama proses produksi berlangsung. Menurut sifatnya biaya produksi dapat digolongkan menjadi 2 yaitu biaya tetap dan biaya tidak tetap. Biaya tetap terdiri dari biaya sewa lahan dan biaya penyusutan alat-alat pertanian, sedangkan biaya tidak tetap yaitu biaya sarana produksi pertanian seperti benih, pupuk, insektisida, dan tenaga kerja. Tabel 4 memperlihatkan biaya tetap usahatani padi sawah di Desa Rimbo Recap dan Desa Watas Marga Kabupaten Rejang Lebong.

Tabel 4. Rata-rata Biaya Tetap Usahatani Padi Sawah dengan menggunakan traktor tangan dan cara konvensional.

\begin{tabular}{llc}
\hline \multicolumn{1}{c}{ No } & \multicolumn{1}{c}{ Uraian } & Jumlah Biaya (Rp/MT) \\
\hline 1 & Benih & $65.645,58$ \\
2 & Pupuk dan Insektisida & $816.786,36$ \\
3 & Tenaga Kerja & $2.206 .158,40$ \\
\hline Jumlah & & $3.088 .589,60$ \\
\hline
\end{tabular}

Sumber: data primer diolah 2014

Dari hasil penelitian, diketahui bahwa benih yang digunakan oleh petani padi sawah di Desa Rimbo Recap dan Desa Watas Marga adalah benih varietas IR 64. Sebagian besar petani menggunakan benih padi yang dibuat oleh petani sendiri yang diambil dari hasil panen sebelumnya. Sebagian lagi diperoleh dari petani lain dengan cara menukarkan degan beras, serta ada juga petani yang membeli di toko pertanian. Salah satu alasan petani menggunakan benih sendiri karena benih padi bersertifikat harganya relatif lebih mahal. Harga benih di daerah penelitian berkisar antara Rp. 6.700,-- sampai Rp. 7.000,- per kilogram. Dari hasil penelitian didapatkan rata-rata besarnya biaya benih yang dikeluarkan oleh petani yaitu sebesar Rp. 65.645,58/MT.

\section{Biaya Pupuk}

Untuk mendapatkan sarana produksi pertanian berupa pupuk termasuk insektisida, petani padi sawah di daerah penelitian membeli sarana produksi di KUD atau toko pupuk terdekat. Jenis pupuk yang digunakan pada usahatani padi sawah di daerah penelitian antara lain adalah: Urea, SP-36 dan Poska. Hasil penelitian menunjukkan bahwa ratarata biaya pupuk dan insektisida yang dikeluarkan oleh petani dalam 
berusahatani padi sawah adalah Rp. 816.786,36/MT, biaya ini sudah termasuk pembelian pupuk kandang untuk persemaian benih. Adapun rincianya yaitu untuk pupuk Urea sebesar Rp. 156.610,6/MT, pupuk SP-36 Rp. 169.713,2/MT dan pupuk Ponska sebesar Rp. 73.954,59/MT sisanya insektisida sebesar Rp. 268.916,75/MT dan pupuk kandang sebesar Rp. $147.546,26 /$ MT.

\section{Biaya Tenga Kerja}

Penggunaan tenaga kerja mencakup kegiatan pengolahan lahan, penanaman, pemupukan, penyemaian, pemberantasan hama dan penyakit tanaman serta pemanenan. Rata-rata biaya tenaga kerja yang dikeluarkan sebesar Rp. 2.098.799,3/MT di luar biaya persemaian. Rata-rata biaya tenaga kerja untuk persemaian benih adalah sebesar Rp. 107.359,13/MT yang dikeluarkan petani padi sawah didaerah penelitian. Jadi total biaya tenaga kerja yang dikeluarkan adalah sebesar Rp. 2.206.158,3/MT. Biaya rata-rata tenaga kerja untuk pengolahan dengan menggunakan traktor tangan adalah sebesar Rp. 2.171.453,66/MT, sedangkan secara konvensional sebesar Rp. 2.026.144,83//MT. Data tersebut diatas belum dapat diartikan bahwa penggunaan traktor tangan akan memperbesar biaya dan cara konvensional lebih menghemat biaya. Di dalam usahatani selain biaya petani juga harus dapat melihat usahataninya dari segi efisiensi waktu dan kemudahan di dalam usahatani. Perbandingannya disajikan pada Tabel 5 di bawah ini:

Tabel 5. Analisis Perbandingan Biaya Pengolahan Lahan Menggunakan Traktor Tangan dan Cara Konvensional

\begin{tabular}{llccccc}
\hline No. & Jenis & $\begin{array}{c}\text { Luas } \\
\text { Lahan }(\mathrm{Ha})\end{array}$ & $\begin{array}{c}\Sigma \mathrm{TK} \\
(\mathrm{Org})\end{array}$ & $\begin{array}{c}\Sigma \text { HOK } \\
(\text { Hari })\end{array}$ & $\begin{array}{c}\text { Upah } \\
(\mathrm{Rp} / \text { Hari })\end{array}$ & $\begin{array}{c}\Sigma \text { Biaya } \\
(\mathrm{Rp})\end{array}$ \\
\hline 1 & Menggunakan & 0.798 & 1 & 3.18 & 200.000 & 635.975 \\
& Traktor Tangan & 1 & 1 & 4.98 & 200.000 & 995.000 \\
2 & Cara & 0.797 & 2 & 5.56 & 50.000 & 546.767 \\
& Konvensional & 1 & 3 & 5.84 & 50.000 & 876.000 \\
\hline
\end{tabular}

Sumber : data primer diolah 2014

Dari Tabel di atas terlihat perbedaan yang cukup besar antara jumlah tenaga kerja, jumlah hari kerja dan upah harian tenaga kerja antara menggunakan traktor tangan dan cara konvensional. Perbedaan tersebut di atas merupakan hal yang wajar, untuk mengetahui hal tersebut perlu dilakukan kajian lebih dalam tentang jenis kegiatan tersebut di atas. 


\section{Biaya Tetap}

Biaya tetap adalah biaya yang tidak tergantung pada besar kecilnya produksi. Biaya tetap yang dikeluarkan oleh petani padi sawah terdiri dari biaya penyusutan peralatan. Besarnya biaya tetap dapat dilihat pada Tabel 6 .

Peralatan pertanian digunakan oleh para petani dalam tahap persiapan lahan, pengolahan lahan, sampai dengan panen. Jenis peralatan yang digunakan adalah cangkul, parang, sabit, hand sprayer dan peralatan lainnya seperti tersebut di atas. Peralatan tersebut tidak habis dalam satu kali pakai atau sekali musim tanam atau musim panen saja, oleh karena itu biasanya disini dihitung biaya penyusutannya. Total rata-rata biaya penyusutan alat-alat pertanian yang digunakan oleh petani padi sawah di Desa Rimbo Recap dan Desa Watas Marga adalah sebesar Rp. 172.027,8/MT. Nilai penyusutan diperoleh dari selisih antara harga awal dikurangi harga akhir dibagi dengan umur ekonomis dikalikan masa tanam hingga ke panen. Besar kecilnya biaya penyusutan peralatan yang harus di keluarkan oleh petani sangat ditentukan oleh besar kecilnya harga komponen tersebut di atas.

Tabel 6. Rata-rata Biaya Tetap Usahatani Padi Sawah Menggunakan Traktor Tangan dan Cara Konvensional

\begin{tabular}{rlc}
\hline No & Uraian & Jumlah Biaya (Rp/MT) \\
\hline 1 & Cangkul & $9,018.30$ \\
2 & Parang & $4,875.70$ \\
3 & Sabit & $4,011.70$ \\
4 & Hand sprayer & $11,422.20$ \\
5 & Ember & $4,583.70$ \\
6 & Tampa(Tampi bambu) & $8,571.80$ \\
7 & Bajak (Alat penghela tradisional) & $7,766.20$ \\
8 & Caplak & $5,757.00$ \\
9 & Garu & $11,108.80$ \\
10 & Terpal & $15,391.10$ \\
11 & Karung & $82,106.70$ \\
12 & Papan Perontok Padi & $5,414.50$ \\
13 & Kaleng Takar & $2,316.40$ \\
\hline \multicolumn{2}{c}{ Jumlah }
\end{tabular}

Sumber : data primer diolah 2014

\section{Total Biaya Usaha tani padi Sawah}

Total biaya produksi pertanian padi sawah merupakan penjumlahan dan biaya tetap dari biaya tidak tetap disajikan pada Tabel 7 . 
Tabel 7 Rata-rata Biaya Produksi Usahatani Padi Sawah Menggunakan Traktor Tangan dan Cara Konvensional

\begin{tabular}{clrr}
\hline No & \multicolumn{1}{c}{ Uraian } & Jumlah biaya (Rp./MT) & Persentase \\
\hline 1 & Biaya Tetap & & \\
& Biaya Penyusutan Alat & $172.027,80$ & 5.30 \\
2 & Biaya Tidak Tetap & & \\
& Biaya Benih & $65.645,58$ & 2.00 \\
& Biaya Pupuk \& Insektisida & $816.786,36$ & 25.00 \\
& Biaya Tenaga Kerja & $2.206 .158,40$ & 67.70 \\
\hline \multicolumn{2}{r}{ Total } & $3.260 .616,40$ & 100.00 \\
\hline
\end{tabular}

Sumber : data primer diolah 2014

Tabel 7 menunjukkan bahwa rata-rata biaya yang terbesar dikeluarkan oleh petani padi sawah di Desa Rimbo Recap dan Desa Watas Marga adalah biaya tenaga kerja yaitu sebesar Rp. 2.206.158,4/MT, atau sebesar 67,7\% dari rata-rata biaya total produksi.

\section{Penerimaan Usahatani Padi Sawah}

Penerimaan usahatani adalah perkalian antara produksi dengan harga jual produksi yang dihasilkan, yaitu dalam bentuk gabah kering dengan satuan kilogram $(\mathrm{Kg})$. Penerimaan dalam penelitian ini adalah pendapatan kotor yang diterima oleh petani dari hasil penjualan padi dalam bentuk Gabah Kering Panen (GKP) yang dikalikan dengan harga. Di daerah penelitian harga gabah sebesar Rp. 2.300/Kg dalam bentuk gabah kering panen. Atas dasar produksi dan harga tersebut, maka dapat dihitung penerimaan total usahatani padi sawah di daerah penelitian yaitu Desa Rimbo Recap dan Desa Watas Marga. Untuk lebih jelasnya dapat dilihat pada Tabel 8 yang menunjukkan perbedaan penerimaan yang didapatkan oleh petani yang menggunakan traktor tangan dan yang tidak menggunakan traktor tangan atau secara konvensioanal dalam sistem pengolahan lahan padi sawah.

Tabel 8. Rata-rata Penerimaan Usahatani Padi Sawah yang Menggunakan Traktor Tangan dan Cara Konvensional

\begin{tabular}{cccc}
\hline No. & \multicolumn{1}{c}{ Jenis } & Jumlah Rp/MT & Jumlah Rp/Ha \\
\hline 1. & Menggunakan Traktor Tangan & $12.312 .797,56$ & $15.437 .308,70$ \\
2. & Cara Konvensional & $12.262 .568,97$ & $15.393 .631,22$ \\
\hline
\end{tabular}

Sumber : data primer diolah 2014

Seperti diketahui bahwa penerimaan dalam usahatani, sangat dipengaruhi oleh jumlah produksi yang diperoleh dalam berusahatani dengan harga produksi itu sendiri dalam satuan di tingkat petani. Untuk

212 | Eddy Silamat, Yuwana dan M. Zulkarnain Yuliarso, Analisa ... 
meningkatkan jumlah produksi di dalam usahatani dipengaruhi oleh berbagai faktor produksi seperti pada pembahasan sebelumnya.

Untuk meningkatkan harga jual diperlukan standarisasi mutu yaitu kwalitas hasil produksi petani harus berkwalitas baik, serta pengolahan lebih lanjut termasuk dalam pengemasan sampai dengan ke pemasaran dan tujuannya, untuk itu diperlukan penelitian lebih lanjut.

\section{Pendapatan Usahatani Padi Sawah}

Pendapatan usahatani sangat ditentukan oleh penerimaan dari produksi yang dihasilkan dan biaya-biaya yang dikeluarkan. Pendapatan usahatani diperoleh dari selisih antara penerimaan total dengan biaya produksi total. Pendapatan usahatani ini sebenarnya merupakan balas jasa tanaman dari kerjasama faktor-faktor produksi yang digunakan. Pendapatan yang diukur adalah pendapatan yang diterima oleh petani dan hasil penjualan gabah padi dalam bentuk gabah kering panen (GKP) setelah dikurangi biaya produksi. Hasil penelitian menunjukkan bahwa rata-rata pendapatan usahatani padi sawah di daerah penelitian adalah sebesar Rp.9.014.727,58/MT, untuk petani yang menggunakan traktor tangan, dan untuk petani yang tidak mengunakan traktor tangan atau secara konvensional yaitu sebesar Rp. 9.041.365,81/MT.

Secara umum dapat dikatakan bahwa kegiatan usahatani padi sawah di daerah penelitian menguntungkan, karena penerimaan lebih besar dari pada pengeluaran. Jika dibagi selama satu kali musim tanam (4 bulan), maka ratarata pendapatan petani padi sawah yang menggunakan traktor tangan adalah sebesar Rp. 2.253.681,9/bulan, dan untuk petani yang tidak menggunakan traktor tangan atau secara konvensional sebesar Rp. 2.260.341.5/bulan pada tabel 9.

Tabel 9. Rata-rata Pendapatan Usahatani Padi Sawah yang Menggunakan Traktor Tanggan dan Cara Konvensional

\begin{tabular}{llcr}
\hline No. & \multicolumn{1}{c}{ Jenis } & Jumlah Rp/MT & Jumlah Rp/Ha \\
\hline 1. & Menggunakan Traktor Tangan & $9.014 .727,58$ & 11.302 .316 \\
2. & Cara Konvensional & $9.041 .365,81$ & 11.349 .945 \\
\hline
\end{tabular}

Sumber : data primer diolah 2014

Pendapatan ini jika dihubungkan dengan jumlah tanggungan keluarga rata-rata sebanyak 4 orang, maka pendapatan yang diterima oleh petani padi sawah di daerah penelitian, bisa dikatakan cukup untuk memenuhi kebutuhan hidup selama satu bulan. Seperti pada pembahasan sebelumnya hampir 50 persen dari seluruh responden di daerah penelitian tidak memiliki pekerjaan sampingan selain usahatani padi sawah. 
Dari hasil perhitungan diperoleh nilai t-hitung sebesar 2.00000067247 lebih kecil dari t-tabel 2.014 pada taraf kepercayaan 0.05 maka demikian $\mathrm{H}_{0}$ ditolak dan $\mathrm{H}_{\mathrm{a}}$ diterima. Artinya tidak ada perbedaan pendapatan petani baik yang menggunakan, maupun tidak menggunakan traktor tangan dalam pengolahan lahan pertaniannya pada usahatani padi sawah di Desa Rimbo Recap dan di Desa Watas Marga.

\section{SIMPULAN DAN SARAN}

Berdasarkan hasil penelitian usahatani padi sawah yang dibandingkan dengan usahatani padi sawah yang menggunakan traktor tangan dan cara konvensional, maka disimpulkan bahwa:

1. Sistem usahatani padi sawah yang dilakukan oleh petani di Desa Rimbo Recap dan di Desa Watas Marga Kecamatan Curup Selatan Kabupaten Rejang Lebong secara umum kegiatannya sama. Perbedaannya hanya terletak pada cara penggolahan lahan saja yaitu menggunakan dan tidak menggunakan traktor tangan. Faktor persepsi petani terhadap penggunaan traktor tangan nilai p-value adalah sebesar $0.001<$ dari alpha 0.05 , jadi tidak ada berpengaruh terhadap keputusan petani untuk menggunakan dan tidak menggunakan traktor tangan. Luas lahan dan persepsi petani terhadap ketersediaan tenaga kerja dapat mempengaruhi keputusan petani menggunakan traktor tangan.

2. Faktor-faktor yang mempengaruhi produktivitas yaitu benih dan insektisida, sedangkan Luas lahan dan pupuk tidak berpenggaruh. Variabel Dummy dari hasil uji t menunjukkan nilai negatif jika dilihat dari tabel 5.4, produktivitas petani yang menggunakan traktor tangan 6.676,94 $\mathrm{Kg} / \mathrm{Ha}>$ dari produktivitas petani cara konvensional yaitu 6.485,19 $\mathrm{Kg} / \mathrm{Ha}$. Dummy menunjukkan ada penurunan produktivitas sebesar $0.2077 \%$ jika petani tidak menggunakan traktor tangan.

3. Pendapatan petani baik yang menggunakan traktor tangan dan tidak menggunakan traktor tangan tidak menunjukkan perbedaan yang signifikan. Pendapatan petani yang menggunakan traktor tangan yaitu Rp. 9.014.727/MT atau Rp. 11. 302.316/Ha dan pendapatan petani cara konvensional Rp. 9.041.365/MT atau Rp. 11.349.945/Ha. Perhitungan hasil uji beda pendapatan atau uji $\mathrm{t}$ nilai t-hitung $2.000<$ dari t-tabel 2.014 yang dapat disimpulkan bahwa perubahan sistem usahatani yang dilakukan oleh petani padi sawah tidak begitu berpengaruh nyata terhadap pendapatan. Hal ini menunjukan bahwa pada usahatani padi sawah dikedua desa secara nilai dalam rupiah tidak menunjukan perbedaan yang signifikan, namun terdapat aspek lain yang dapat dinilai terutama pada penggunaan traktor tanggan seperti kecepatan, efektifitas serta upaya dalam menghadapi kelangkaan tenaga kerja. 


\section{Saran}

Upaya peningkatan swasembada pangan oleh pemerintah bertujuan untuk meningkatkan pendapatan petani terutama petani padi. Untuk mencapai program tanam dan panen padi 3 (tiga) kali setahun penyediaan alat mesin pertanian merupakan solusi terbaik, sebagai upaya percepatan mekanisasi pertanian. Upaya percepatan mekanisasi pertanian, dalam mendukung program swasembada pangan diharapkan bukan hanya menjadi tanggung jawab pemerintah saja, tetapi menjadi tanggung jawab pihak swasta dan stakeholder yang turut serta dalam pengembangan pertanian.

CATATAN: Artikel ini bagian dari thesis atas nama Eddy Silamat

\section{DAFTAR PUSTAKA}

Bunasor. 2006. Pengembangan UKM Dalam Mendukung Pembangunan Pertanian Yang Berkelanjutan.Makalah Seminar Nasional Revitalisasi Kebijakan Menuju Industrialisasi Pertanian Yang Berkeadilan dan Berkelanjutan. Balai Senat UGM. 8-9 Desember.

[BPS]. Badan Pusat Statistik. 2012. Produktivitas Produksi Tanaman Pangan Propinsi Bengkulu. Bengkulu: BPS.

Gujarat. 2003. Basic Econometrics. Internasional Edition. Irwin McGraw-Hill. Singapore.

Hamidah H. dan Teguh Soedarto. 2006. Analisis Oprasional Traktor Tangan Pada Usaha Playanan Jasa Alsintan Pola Kerjasama Oprasional Di

Kab. Gresik."Journal Ilmu-Ilmu Ekonomi, Vol. 6, No. 2, September, 2006:76-85.

Kamila M. 2011. Tingkat Adopsi Teknologi Terhadap Pelaksanaan PTT (Pengelolaan Tanaman Terpadu) Padi Sawah Di Kecamatan Tugumulyo Kabupaten Musi Rawas. Tesis Program Studi Pasca Sarjana Pengelolaan Sumberdaya Alam dan Ligkungan. Fakultas Pertanian Universitas Bengkulu.

Nursidah. 2003. Analisis Operasional Hand Traktor di Daerah Istimewa Yogyakarta. Tesis. Program Pasca Sarjana Fakultas Pertanian UGM. Yogyakarta.

Susanto, U., A. Daradjat, dan B. Suprihatno. 2003. Perkembangan Pemulian Padi Sawah di Indonesia. Jurnal Litbang Pertanian. Vol 22(3).

Tjakrawilaksana A. 1983. Usaha Tani. Departemen Ilmu-Ilmu Sosial Ekonomi Pertanian. Fakultas Pertanian IPB. Bogor.

Umar H. 2004. Metode Penelitian Untuk Skripsi dan Tesis. Raja Grafindo Persada. Jakarta. 